\title{
Introduction
}

This bibliography began very casually in early 1976 , with a request from a professor of music at Santa Barbara for a list of settings of Blake poetry for male chorus. The reference librarian (myself) who was approached for this information thought it would be no great matter to provide it. There were, after all, comprehensive bibliographies of musical settings for the poetry of Shakespeare, Shelley, Browning, Emily Dickinson, and others; it ought to be a simple matter to find one for Blake and extract the needed details.

Unfortunately, there was none. There were occasional lists in the Blake Newsletter and Martin Nurmi published a brief "Note on Musical Settings" in Bentley and Nurmi's A Blake Bibliography (1964), but no comprehensive list appeared to exist. Eventually a page of some twelve or thirteen of the requested settings for male voice was scraped together, sent off, and apparently satisfied the need. It was an interesting search, however, and a subsequent exchange of letters with Blake scholars and musicians suggested that a full bibliography of Blake settings might be welcomed. This book is the result.

The use of Blake's poetry by composers is almost entirely a twentieth-century phenomenon, but not quite. And until recently it has been confined largely to the English-speaking world. The earliest reported settings of Blake poetry are those purportedly made by Blake himself. His first biographer, Alexander Gilchrist, reported that Blake was in the habit of singing his poems to melodies of his own making and that his friends were impressed with these efforts; a particularly vivid scene was that of his deathbed, when "he lay chaunting Songs to Melodies - both the inspiration of the moment." This music, whatever its worth, was not recorded, and the only tune of his time actually identified was a Vauxhall Gardens song by John Worgan which Blake used as the music for his poem The Shepherd. The earliest person to suggest a Blake text for music was apparently not a musician at all, but the Unitarian minister James Martineau, who in about 1874 proposed the text "Can I see another's woe" for use as a hymn; two years later Doyne Courtenay Bell made the first art-song setting of this text. Jacques Blumenthal set it again in 1878, along with the first considerable number of other Blake texts. The young Englishwoman Mary Carmichael was apparently the first of her sex (in 1876) to publish settings of 
Blake; she was followed in 1878 by Edith MacDonald. Women are, in fact, a small but substantial minority of composers in Britain, Canada, the United States, and elsewhere who have been drawn to Blake as a source of inspiration.

In the 1880 s interest among musicians began to widen, and larger numbers of Blake songs appeared, generally solo voice settings but some part-songs as well. Along with the lesser knowns, there were composers whose names still figure in music history, such as Basil Harwood and Arthur Somervell. It was still largely an English affair, though the first Irishman, Hastings Crossley, produced a setting of Sunflower in 1889. The Welsh, Scots, Americans, Canadians, New Zealanders, and Australians do not begin to appear until after the turn of the century. The first to publish a setting of the complete Songs of Innocence, in 1891, was the public servant and amateur musician Sir Vincent Caillard. Throughout the decades since, Blake has continued to appeal to amateur as well as professional musicians.

One result of this extended search for Blake settings was to discover that composers, even of what is called "serious" music, seemed to sort themselves out by levels of seriousness. This is evident in their choice of lyrics for songs. Until the mid-nineteenth century it seems to have been a very usual practice for composers to be their own lyricists. There were exceptions, of course; Shakespeare, Herrick, and a few others among the classic poets of England have always appealed. But from mid-century forward, the parlor songs of England were dominated by the verse of Felicia Hemans, Adelaide Proctor, Barry Cornwall, and the two Edwards, Oxenford and Teschemacher - names now hardly known to English literature. Composers who used the verse of these writers almost never noticed Blake. His poetry, although it was now reappearing in new editions, was simply not used by the majority of songwriters before 1900. A few of the more perceptive composers Walford Davies and William Hadow - began to set his poems in the $1890 \mathrm{~s}$, but others of their generation - Brewer, Stanford, Parry, Boughton - did not turn to him until a decade or so later. In such an environment William Blake made his way very slowly. What one sees in the literature of song lyrics, however, is a gradual decline in the popularity of these other versifiers until they disappear altogether from the musical scene in about 1920 . By then Blake had emerged into prominence as a poet worthy of serious attention by the best composers of the age. At that point he faced competition (as a lyricist) from a new generation of poets - De la Mare, Dickinson, Pound, and Yeats - and managed to hold his place very well.

The years from 1900 to 1914 were the heyday of the "coon" song, as in Coon Up $a$ Tree or Coon From the Moon or A Coon and His Gal. Unbelievable numbers of these songs were produced, in both England and America, as one can tell from reading the British Library's Catalogue of Printed Music. It is a musical and social phenomenon worth investigation. Now all are forever banished, and one notes with some relief that no composer who worked with Blake texts was found to have perpetrated one of these ditties. The few settings of Blake's Little Black Boy which date from this period were done in a quite different spirit, as the intent of the poem, indeed, demanded. Virgil Thomson's fine setting of this poem became an apparent victim of misguided concern on this point. As one of his Five Songs from William Blake it was recorded by Mack Harrell and issued thus in 1954, but following the 
tumult of the sixties and seventies it was dropped from the 1979 reissue of the recording, which then became Four Songs.

Far and away the most popular of the Blake poems, as a lyric, is The Lamb; well over 250 settings have been found, and others seem to turn up every month. This is followed, at some distance but still with substantial numbers, by the two Cradle Songs ("Sweet dreams, form a shade" and "Sleep, sleep, beauty bright"). Other familiar favorites, The Tyger, The Shepherd, Spring, follow along in lesser numbers. It ought to be possible to show changes in musical and literary taste by examining the use of Blake texts from the beginning until the present. But Blake has always appealed to such a wide variety of readers and composers that any progression of interest might well be obscured. One can, however, detect a gradual enlargement of focus from the songs to passages from the "prophetic books," Milton, Jerusalem, and The Marriage of Heaven and Hell.

The music critic Andrew Porter has recently remarked, apropos the Blake Songs of Innocence and Songs of Experience, that "there can be few English-speaking composers who ... have not contemplated setting all forty-six of the poems." The success of the American William Bolcom in doing so is the more extraordinary in that so few have actually realized any substantial part of that dream. Bolcom is alone in having used all 46 poems in a single sustained effort. Many others, as this bibliography will show, have set substantial numbers of the poems, though not often as a connected set, and most were for fairly limited musical resources. Among English composers there is Havergal Brian with 19, Fritz Hart with 26, Alfred Hale with 17, and Maud Valerie White with 15. Both Vincent Caillard and Ronald Stevenson have set the complete Songs of Innocence as a cycle, the first for voice and piano, the second as a choral cycle with solo voice and chamber orchestra. Another relatively unknown Englishman, John Sykes, came close to using all 46 poems with his two cycles of 16 and 20 songs, the one from Innocence and the other from Experience. The Australian Rudolph Werther set 17 of them, in several groups. In America Norman Curtis has made a cycle of 33 of the poems and proposes to do the rest. Timothy Lenk has set 15 for two soloists and chamber ensemble. The poet Allen Ginsberg has recorded his arrangements of 22 of the poems and is reported to have recorded his tunings of the others, on a second album that has not actually been issued. Elizabeth Swados recently (1981) made an hour-long television program for CBS which used many of the poems; she and the much earlier Maude Valerie White have been the only women with the persistence, or perhaps the devotion, to set so many of the Blake texts. With the exceptions of Stevenson, Lenk, Swados, and Ginsberg with his harmonium and guitar, all these settings of Blake were for solo voice and piano. Bolcom, again, is alone in the size of the musical forces he has used, and his general success has been such as to give him a special distinction among "Blake" composers.

Settings by composers outside the English-speaking world have, until recently, been relatively few and, with one exception, all date from the post-World War II period. The exception is the Finnish conductor and composer Erkki Melartin, whose setting of Blake's Cradle Song dates back to 1910 . There have been many other Scandinavians: Østein Sommerfeldt, whose recent (1978) Blake settings have 
been heard in the United States through concerts sponsored by the NorwegianAmerican Foundation. Lars-Erik Larsson of Sweden published a choral setting of a text from Proverbs of Hell, using a Swedish translation which was then retranslated into English by Norman Luboff for its 1969 publication in this country; more recently Sven-David Sandström has made important contributions to Blake-inspired music, both choral and instrumental. A cluster of young Finnish composers, led by Leif Segerstam but including the conductor Ilkka Kuusisto, and younger composers such as Arto Rintamäki and Ari Taskinen, have brought Blake to the far shores of the Baltic Sea. Denmark since the war has been a veritable hothouse of Blake interest. Among at least ten who have done significant work there are Poul Rovsing Olsen and John Väinö Forsman who made a number of settings in the late forties and early fifties, Leif Thybo who completed two in 1974, and Bo Holten who is a leader in the generation of the Eighties. Postwar activity on the continent extends to West Germany, to Switzerland, Austria, and even to Hungary where at least three composers, most recently Zoltan Jeney, have made interesting song settings. Sovietbloc nations, for the most part, have yet to discover Blake, but two young Russians, Dimitri Smirnov and Elena Firsova, have made startling use of Blake texts in songs, chamber works, operas, and large symphonic works. For Smirnov, in particular, 1989 was an important year with performances of Blake works in West Germany, Britain, and the U. S. In the Latin countries Blake is still apparently little known among composers. There is André Laporte in Belgium, René Koering in France, and Paolo Renosto in Italy, but the showing is very sparse. In Holland there are several including the energetic Peter Schat whose anti-war, anti-Vietnam extravaganza, Het Vijfde Seizoen (1973), incorporated Blake's poem Day as a refrain. The two choral settings of René Leibowitz are somewhat difficult to place in this scheme of national origins, in that they were composed in Madrid and Paris, by a Polish-French composer and published in the United States - with English and French texts. The Blake settings produced by Hindemith, Krenek, and Toch are in a different category from any of the foregoing, since they were written and published in this country while the composers were living here.

There are some rather surprising absences from this bibliography of songwriters. There is no Delius or Elgar, no Finzi or Rubbra, from Britain, and no Barber or Diamond or Dello Joio from the United States. Some of the most skillful composers of art songs in this century are unrepresented and others are represented by only a single Blake piece. Why this is so might make a subject worthy of study. At this late hour it can hardly be lack of acquaintance with the poet. And the poems themselves are universally acknowledged as lending themselves to musical treatment. For some there may be a feeling that many of the poems have been overused and there is nothing more to be said; for others, perhaps, there is a feeling that the texts are a bit too restrictive. These are understandable reactions. And in response one may say that many, indeed, of the settings described in this bibliography are pleasant enough items that do not delve very deeply into the texts, but that those composers who have achieved the most with Blake are those who have discovered the revolutionary poet who lives just below the surface of the innocent words. 
For some the use of Blake seems to reflect only a passing interest; for others it seems to have been a more profound identification with the poet. The songs of O'Neill or Rajna or Randall Thompson were early student efforts - which did not preclude their being well made and effective music. Blake in the music of such as Britten, Tippett, or Vaughn Williams, of Bedford, Luening, or Nachmanovitch is a very different matter. Presumably all those who have set large numbers of Blake texts over extended periods of time have been more deeply affected by the poet and may possibly have entered more deeply into his vision of reality. To give but two examples, Otto Luening (Odyssey of an American Composer) and the Dane Ole Carsten Green have recounted how the discovery of Blake altered their perceptions of life and affected their work as musicians.

Stylistically, there is an immense variety among the settings. Looked at as a whole, this body of music might be characterized as "classical": much of it is written in traditional harmonies, melodies, and rhythms, at various levels of sophistication, from simple school songs to very elaborate choral works employing traditional contrapuntal techniques. Composers have often been seduced by the seeming simplicity of the poems, especially the Songs of Innocence and some of the others, into using trite harmonies and an all too tempting triplet rhythm that seems to fit rather too easily the metre of the poems. This is especially true of much music written for younger audiences. Art songs are a different matter. They range from the heavy post-Romantic chromaticism of Sidney Homer to the bright simplicities of Virgil Thomson. Benjamin Lees employs an aggressive dissonance that cuts away decades of cloying sweetness, and the Black American composer John Price fights off the skipping rhythm of much older Blake music by dropping bar lines altogether and in the process creates a most striking and effective setting of My Silks and Fine Array. The folk idiom of the sixties is also well represented in the settings of Allen Ginsberg, Ed Sanders, Lucy Simon (Carly Simon's talented sister), Tom Nichols, and the Canadian Gregory Forbes. Much of the music listed here is unpublished and much of it derives from academic environments. It would seem that current fashions in the teaching of composition might well be documented from examples to be found here. Serialism, atonality, the current "international" style are much in evidence in these settings, but so is Broadway and Hollywood in the several music theater productions, and jazz (to make an end to this list) is also very successfully represented by the instrumental interpretations of David Axelrod and Mike Westbrook.

The bibliography includes solo songs, choral works, chamber and orchestral works with vocal parts, and other works without voice but manifestly inspired by the works of Blake. I have not included a number of items which had what seemed to be pretty obvious Blake titles, because on checking (often with the composer) I found that the Blake reference was incidental at best, or that the text was by another author altogether. A case in point is John Adams's colorful orchestral piece of "minimalist music," Fearful Symmetries (1988), where the title taken from Blake's poem The Tyger is simply the composer's self-deprecating way of acknowledging the insistent rhythmic pulse of the work. The American Alec Wilder and Rob du Bois of the Netherlands have both published cycles entitled Songs of Innocence, each 
however, without any text by Blake. And there were many fruitless searches after Cradle Songs, Pipers, Shepherds, Tigers, and even Little Boys Lost, only to be reminded in the end that these titles were common to poets other than Blake. What has been included I am confident is closely enough associated with Blake, though it has not been possible to examine every piece of music in person.

The table of Blake settings shown below gives something of a visual history of compositional interest in his work.

$\begin{array}{lccc} & \text { Published } & \text { Unpublished } & \text { Total } \\ 1870-79 & 10 & 0 & 10 \\ 1880-89 & 16 & 0 & 16 \\ 1890-99 & 56 & 3 & 59 \\ 1900-09 & 60 & 1 & 61 \\ 1910-19 & 171 & 22 & 193 \\ 1920-29 & 151 & 30 & 181 \\ 1930-39 & 98 & 72 & 170 \\ 1940-49 & 98 & 125 & 223 \\ 1950-59 & 185 & 104 & 289 \\ 1960-69 & 233 & 247 & 480 \\ 1970-79 & 173 & 463 & 636 \\ 1980-89 & 83 & 212 & 295 \\ \text { Undated } & 5 & 63 & 68\end{array}$

It has been observed that the English art song reached a highpoint of achievement somewhere in the period of the First World War and the decade following. If that was so, then the table certainly shows that Blake's poetry shared in that achievement, but the real height of Blake popularity seems to have come some forty years later in the 1960 s and 1970 s. The settings are tallied above in the decades in which they were composed, not, as in a few cases, in the later decades when they were published. The distinction between published and unpublished music becomes increasingly unclear, with the onset of self-publishing and easy photocopy. These latter developments may, in fact, be a factor in the enormous increase of unpublished Blake music in the 1970s. The ' 80 s have not yet been entirely heard from (bibliographically speaking), but there has been some apparent falling off of composer interest in the poet, though it remains high - higher than at any time before 1960. Each generation of readers and musicians makes its own discovery of Blake. Several composers have written to describe further Blake projects that they have in progress. With these encouraging words and the recent splendid achievements of such composers as the Russian Dmitri Smirnov freshly in mind, the promise of future Blake music remains bright. We can be certain that we will be shown beauty in the musical interpretation of his work that we had not known before. 


\section{EXPLANATION OF ENTRIES}

The arrangement is alphabetical by composer. In a few places, cross-references are made from one form of the name to another, where it has been observed that directories and bibliographies do not agree on a single form of the name. Birth and death dates are included when available, as well as the composer's nationality. A considerable effort has been expended on these biographical details, and if nothing is shown, it is not for lack of trying. Where more than one country appears with the personal name, it usually means that the composer began his career in the first shown and later took up residence in the second. Names in brackets are those composers, such as Bach, Beethoven, Mahler, Penderecki, whose music has been adapted for use with Blake texts by other, and usually later, persons.

The titles of compositions have been entered as shown on the printed music, or as provided by composers, publishers, or printed bibliographies, with one exception: the attribution of the text to Blake has been silently omitted except where his name is an integral part of the title, as in Sacred Songs of William Blake or Ten Blake Songs.

Every effort has been made to show the performing combination, as a service to musicians looking for possible Blake material to perform. Regrettably, a few entries lack this essential information; these are generally for unpublished music listed in the U.S. Copyright Office's catalog of copyright entries for music. One may hazard the guess that these compositions are songs for voice and piano, but it has not been possible to locate either the composer or a copy of the work in order to verify the entry or expand the information. Any entries that are incomplete for lack of such information are identified by the asterisk $\left({ }^{*}\right)$ at the head of the entry.

Another matter on which a great effort has been expended is the dating of the music. Trends in the use of Blake texts can hardly be studied without some indication of when they were used. For printed music, the date of publication is often the only date available. Where dates of composition are obtainable, from notes in the scores or from other sources, these have been indicated by separate notes in the entries.

The length of each piece of music is shown by the pagination or the duration or both. Publishers' series notes and plate or catalog numbers are included where known. If more than one Blake text is used in a work, a contents note is included. Following this there are often other notes to indicate the nature of the music in question: commissions, first or other significant performances, dedications. Notes on both commercial recordings and private tapings are included whenever the information has been available.

The next-to-last item in each entry is usually a biographical note. Since many of the composers are little known in the current music world, and perhaps quite unknown to literary scholars, it seemed a useful gesture to include biographical identification wherever it was possible to obtain one. For the famous names, a simple reference to New Grove or Baker seemed sufficient; for others it was necessary to go farther afield for references or to create an identification from what was discoverable. References to the monographic literature, of which there is 
sometimes an abundance, are made only when a work offered a useful or significant comment upon the Blake composition.

The final item in each entry is a note on sources from which the information in the entry was obtained. No attempt has been made to show all the references where an item may be listed. On the other hand, there is an attempt to provide locations where the work in question may be found. The matter of availability is important. Unpublished works ("ms." in the entries) are often shown as available from the composer or from an agency, such as the Scottish Music Archive or the American Music Center and the American Composers Alliance, who will supply photocopies of titles in their collections. Older printed materials (i.e., pre-1960) are often out of print. Some publishers (e.g., Novello or Boosey \& Hawkes) will supply photocopies from their file copies. Some American libraries will lend; NYPL and some others will not. The Music Division of the British Library will supply photocopies from its depository copies, upon completion of a permissions form.

\section{ACKNOWLEDGMENTS}

This bibliography of Blake-inspired music owes much to the interest and help of composers, librarians, publishers, and their associates around the world. A special note of thanks must go to $\mathrm{O}$. W. Neighbour, Nicholas Chadwick, and the staff of the Music Division of the British Library - the largest single repository of printed music listed here - for unfailing kindness in person and for many exchanges of letters about troublesome points. Thanks for similar help go also to the reference staff of the New York Public Library, the American Composers Alliance, the American Music Center, and (at the Library of Congress) to the staff of the Copyright Office and the Music Division. A high proportion of the music described here is unpublished, and for help with the bibliographic description of it I am also indebted to the archivists and staff of music centers in several countries: Matthew Greenall at the British Music Information Centre (London); the Scottish Music Information Centre; the Guild for the Promotion of Welsh Music; Angela Gaffikin at the Australia Music Centre; to Patrick Ring, Radio Telefis Eireann, for help with several Irish composers; to Bendt Viinholt Nielsen, Danish Music Information Center; Jan Olof Rudén, Svensk Musik; Matti-Jussi Pollari and Marketta Kuusipalo, Finnish Music Information Centre; Diana von Volborth, CeBeDeM (Brussels); Walburga Litschauer, Österreichische Gesellschaft für Musik; Balint Andras Varga, Editio Musica Budapest. For Canadian composers there was much appreciated help from Mark Hand, Canadian Music Centre (Toronto), and Marlene Wehrle, the National Library (Ottawa). Particular thanks to the composers themselves who answered my inquiries, often with a photocopy of the music in question, and occasionally provided information about other unpublished work of theirs or of colleagues to swell the total. Thanks to the many people in distant places who called or wrote on my behalf and then shared what they had been able to find. Thanks to the publishers who provided examination copies of in-print music and who gave information about out-of-print music from their archival copies. Thanks 
to the interlibrary loan staff of the Library, University of California, Santa Barbara; to music librarians Susan Bower and Martin Silver; and to the Librarians Association of the University of California, both statewide and the Santa Barbara Division, for two research grants, which helped materially to bring this project to completion. The copyediting of Gladys (Pat) Castor and the helpful advice of Rose Anne White, series manager for the University of California Press, have done much to improve the presentation of the text. On a more personal note, I thank my sister, the soprano Brenda Fairaday, in Manhattan, for many suggestions for additions to the list of composers and for looking up bibliographic details for me in New York. Finally, a measure of thanks to my daughter-in-law Jean Brayfield Fitch and my son Steve for the beautiful computerized format in which this bibliography now appears.

The illustrations which enhance this bibliography were chosen from the drawings and engravings of Blake to show his artistic use of musical themes. They are reproduced by permission of The Huntington Library, San Marino, California, from original volumes in their possession. My thanks to Professor Robert Essick for help in locating them. The title page vignette is from Edward Young's Night Thoughts, p. 16. Other illustrations are from Joseph Ritson's $A$ Select Collection of English Songs (p. xxix), from Blake's The Book of Job, plate 21 (p. 256), and from The Songs of Innocence and Experience: "The Piper" (p. 128) and "The Voice of the Ancient Bard" (p. 143).

\section{Santa Barbara, August 1989}

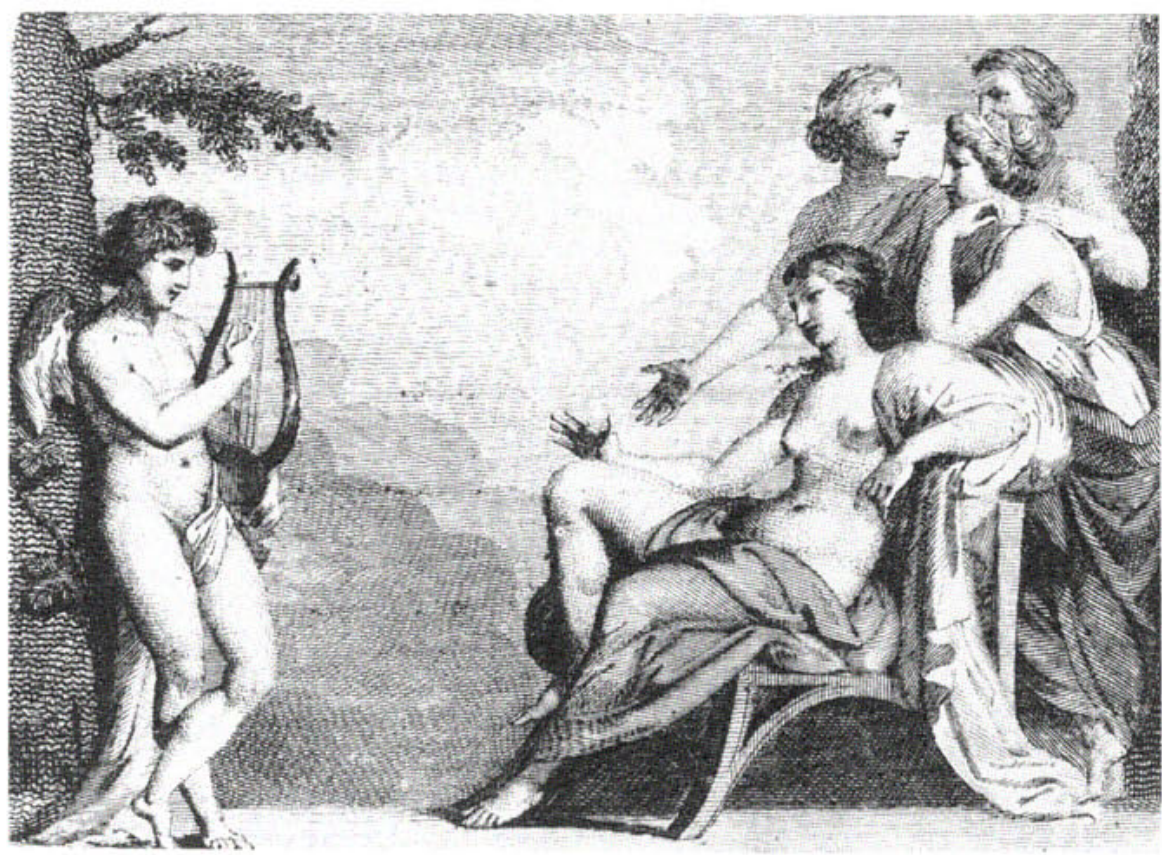


